\title{
PKMS Kelompok Konveksi Rumahan dalam Upaya Peningkatan Pendapatan Rumah Tangga di Desa Jolotundo Kecamatan Lasem, Kabupaten Rembang
}

\author{
Siti Alliyah, Rifqi Suprapto \\ STIE YPPI Rembang \\ wildankafa@yahoo.co.id
}

Key word:

Counseling;

Training;

Accompaniment

; bookkeeping;

the blog

\section{Kata Kunci}

Penyuluhan;

Pelatihan;

Pendampingan; pembukuan; blog

\section{Abstract}

The PKMS program was carried out in Jolotundo Village, Lasem District, Rembang Regency with Kenanga Sewing Group partners. Jolotundo village is famous for its citizens, especially women who open home-made convection. By seeing the business potential which is still very broad and the convection business is one of the leading sectors of Jolotundo Village, then home-based convection should have priority so that it can develop as one of the sectors that will increase people's income. The purpose of this program is to increase the income of the Kenanga Convection Group. The methodology used is counseling, management and entrepreneurship training and e-commerce practices. The results of the PKMS program include: 1) the partner group is able to create an online shop (Tokopedia) and a blog 2) the partner group is able to make good and orderly financial accounting 3) the partner group starts to dare to make products without relying on orders, 4) the partner group products have used packaging with complete hangtags and brands on the product.

\section{Abstrak}

Program PKMS ini dilaksanakan di Desa Jolotundo, Kecamatan Lasem, Kabupaten Rembang dengan mitra Kelompok Jahit Kenanga. Desa Jolotundo terkenal dengan warganya terutama perempuan yang membuka konveksi rumahan. Dengan melihat potensi usaha yang masih sangat luas serta usaha konveksi merupakan salah satu sektor unggulan Desa Jolotundo, maka sudah seharusnya konveksi rumahan mendapat prioritas sehingga mampu berkembang sebagai salah satu sektor yang akan meningkatkan pendapatan masyarakat. Tujuan dari program ini adalah untuk meningkatkan pendapatan Kelompok Konveksi Kenanga. Metodologi yang dilakukan adalah penyuluhan, pelatihan manajemen dan kewirausahaan dan praktek e-commerce. Hasil dari program PKMS antara lain: 1) kelompok mitra mampu membuat toko online (Tokopedia) serta blog 2) kelompok mitra mampu membuat pembukuan keuangan yang tertib dan baik 3) kelompok mitra mulai berani membuat produk dengan tanpa mengandalkan pesanan, 4) produk kelompok mitra telah menggunakan kemasan dengan dilengkap hangtag dan merk pada produk. 


\section{PENDAHULUAN}

Berdasarkan data Kementerian Koperasi dan UKM pada tahun 2017 bahwa kontribusi UKM terhadap product domestic bruto (PDB) sebesar 60,34\%, sedangkan UB sebesar 39,66\% dan kontribusi UKM dalam penyerapan tenaga kerja sebesar $97,22 \%$, sedangkan UB sebesar 2,78\% (Kementerian Koperasi dan UKM, 2017). Persentase tersebut diharapkan akan terus meningkat pada tahun-tahun mendatang dikarenakan pertumbuhan ekonomi Indonesia yang semakin membaik. Data global telah menunjukkan kontribusi yang signifikan dari UKM dimana rata-rata 95\% dari kondisi ekonomi disebagian besar negara bergantung pada UKM. Semakin ketatnya kompetisi antara UKM dan perusahan besar, UKM harus mencari keunggulan kompetitif yang dapat membantu mereka dalam meminimalkan biaya dan memaksimalkan laba.

Mayoritas UKM di Kabupaten Rembang telah menerapkan Informasi Akuntansi Manajemen. Informasi Sistem Akuntansi Manajemen berpengaruh positif siginifikan terhadap kinerja manajerial, (Alliyah, 2014). Kemudian tahun 2015 hasil penelitian tentang informasi Sistem Akuntansi Manajemen di Kabupaten Rembang juga menunjukkan hasil yang konsisten bahwa Informasi SAM berpengaruh positif signifikan terhadap kinerja manajer UKM, (Alliyah, 2015).

Salah satu desa yang mempunyai UMKM potensial adalah Desa Jolotundo Kecamatan Lasem Kabupaten Rembang. Rata-rata UMKM di desa tersebut belum mempunyai manajemen usaha yang baik, seperti belum adanya legalitas usaha, dan pemasaran yang kurang baik. Pencatatan keuangan telah dilakukan, namun belum sesuai dengan standar SAK EMKM.

Desa Jolotundo terletak di Kecamatan Lasem, Kabupaten Rembang mempunyai luas 112.400 Ha. Secara geografis Desa Jolotundo di sebelah Utara berbatasan dengan Desa Karangturi, Sebelah Selatan Berbatasan dengan Desa Tuyuhan, Sebelah Barat Berbatasan dengan Desa Babagan dan sebelah Timur Berbatasan dengan Desa Sumbergirang. Jumlah penduduk Desa Jolotundo adalah 3.726 jiwa dengan 18 RT dan 8 RW, yang sebagian besar penduduknya bekerja di sektor pertanian dan pertukangan (BPS Kabupaten Rembang, 2016).

Desa Jolotundo terkenal dengan warganya terutama perempuan yang membuka konveksi rumahan. Dengan melihat potensi usaha yang masih sangat luas serta usaha konveksi merupakan salah satu sektor unggulan Desa Jolotundo, maka sudah seharusnya konveksi rumahan mendapat prioritas sehingga mampu 
berkembang sebagai salah satu sektor yang akan meningkatkan pendapatan masyarakat. Perkembangan konveksi rumahan sangat membantu perekonomian desa. Di desa Jolotundo terdapat 15 konveksi rumahan. Mereka tergabung dalam kelompok konveksi rumahan yaitu Kelompok konveksi Kenanga. Dengan mengembangkan konveksi rumahan kelompok Usaha Kenanga berupaya mengikuti kegiatan untuk meningkatkan kemampuan entrepreneur terutama dalam hal peningkatan kemampuan produksi dan penjualan. Kegiatan yang diikuti diantaranya mengikuti Rembang Ekspo yang diselenggarakan oleh Pemerintah Kabupaten Rembang. Selain itu juga hasil karya mereka juga pernah digunakan dalam kegiatan Dekranasda Kabupaten Rembang.

Produk yang dihasilkan oleh kelompok konveksi Kenanga adalah baju anak dan dewasa maupun seragam kantor yang sering dipesan oleh pelanggan. Setiap bulan jumlah baju yang dihasilkan dari penjahit di desa Jolotundo semakin berkembang, apalagi dengan didukung potensi Lasem dengan adanya batik tulis Lasem. Usaha yang dilakukan kelompok Kenanga untuk menunjang berkembangnya konveksi rumahan di desa Jolotundo, diantaranya beberapa anggota kelompok ada yang mengikuti kegiatan Rembang Ekspo yang diselenggarakan oleh
Pemerintah Kabupaten Rembang. Selain itu usaha pihak desa untuk menjadikan konveksi rumahan ini sebagai produk unggulan desa, adalah bekerjasama dengan pengusaha batik lasem. Sehingga pengusaha batik lasem tidak hanya menjual kain batik, tetapi juga dapat menjual baju batik. Perkembangan usaha batik tulis Lasem tentu menjadikan industri konveksi rumahan di Desa Jolotundo juga ikut berkembang.

Namun demikian perkembangan industri konveksi di Desa Jolotundo tidak diimbangi dengan pengelolaan manajemen yang baik. Tidak adanya pemasaran yang modern baik berupa brosur, spanduk maupun pemasaran secara online. Selain itu keterbatasan modal dan pengelolaan keuangan juga masih menjadi kendala mitra.

Konveksi rumahan yang tergabung dalam kelompok Kenanga sebanyak 15 orang. Jika order pelanggan cukup besar misalnya untuk pesanan seragam kantor, mitra akan menambah tenaga kerja harian dan membayar upah per hari. Adapun pencatatan keuangannya dilakukan sendiri oleh pemilik meskipun belum konsisten dijalankan namun pemilik sudah memiliki buku catatan penerimaan dan pengeluaran kasnya. Namun demikian informasi keuangan yang akurat belum dapat diketahui karena keuangan usaha dan keuangan pribadi masih belum dipisahkan. 
Pembukuan secara rutin pernah dilakukan pada tahun 2014, namun karena masingmasing anggota hanya fokus pada produksi, maka pencatatan keuangan untuk selanjutnya tidak dilakukan. Berkembangnya usaha hanya mampu dilihat dari hasil produksi jahit yang dihasilkan. Namun keuntungan secara pasti tidak mereka ketahui, karena kurangnya minat dan pengetahuan akan manfaat pencatatan keuangan.

Permasalahan yang dihadapi mitra yaitu mitra belum mengetahui bagaimana penyusunan laporan keuangan yang baik. Mitra belum memahami bagaimana pencatatan keuangan yang tepat sehingga mitra masih belum dapat mengetahui berapa laba/rugi setiap bulannya. Selain itu seringkali mitra merasa bahwa setiap harinya ada pendapatan penjualan namun arus kas usaha tidak sesuai dengan perkiraan mitra. Hal ini disadari mitra karena masih menggabungkan antara keuangan pribadinya dengan usaha yang dijalankan. Pemasaran yang belum baik juga menjadi kendala dalam mengembangkan usaha mitra.

Permasalahan yang dialami oleh mitra disebabkan karena mitra belum mengetahui dan memahami manajemen pemasaran dan keuangan (prinsip akuntansi). Salah satunya adalah konsep kesatuan usaha (Economic Entity Concept). Konsep kesatuan usaha memandang bahwa perusahaan adalah sebagai suatu entitas yang terpisah dari pemiliknya. Berlandaskan konsep ini maka ilmu akuntansi menyajikan gambaran tentang suatu usaha sebagai entitas yang berdiri sendiri, tidak tercampur dengan pemiliknya.

Berdasarkan data yang diperoleh dan wawancara dengan ketua kelompok konveksi Kenanga permasalahan prioritas mitra dari aspek manajemen pemasaran dan keuangan yang disepakati bersama adalah sebagai berikut:

1. Keterbatasan modal

2. Belum adanya pemanfaatan media pemasaran

3. Belum terpisahnya keuangan pribadi dengan keuangan usaha

4. Rendahnya pengetahuan pengelolaan keuangan dan bagaimana penyusunan laporan keuangan berbasis SAK EMKM

5. Terbatasnya pengetahuan tentang pembuatan laporan keuangan

6. Belum adanya teknologi untuk mendukung pengembangan usaha (ecommerce)

7. Belum adanya institusi yang secara intens memberikan pembinaan dalam mengembangkan usaha dan meningkatkan pendapatan pelaku konveksi rumahan. 
Permasalahan yang telah disepakati dalam wawancara dengan ketua kelompok konveksi rumahan Kenanga Desa Jolotundo dengan Tim pengusul program Kemitraan Masyarakat Stimulus (PKMS) untuk menjadi prioritas yang harus segera diselesaikan adalah: (1) Permasalahan modal usaha, (2) Permasalahan media pemasaran online, (3) Permasalahan belum terpisahnya keuangan pribadi dengan keuangan usaha (4) Permasalahan rendahnya pengelolaan keuangan, (5) Terbatasnya pengetahuan tentang pembuatan laporan keuangan,

Permasalahan belum adanya institusi yang secara intens memberikan pembinaan dalam mengembangkan konveksi rumahan.

\section{METODE PEMECAHAN MASALAH}

Metode pelaksanaan dalam usaha memberikan solusi pada permasalahan usaha konveksi dalam pengelolaan manajemen melalui tahapan sebagai berikut:

\section{Perencanaan}

Agar program ini berjalan dengan baik dan maksimal, maka diperlukan perencanaan secara tepat, diantaranya:

a. Menganalisis proses pelaksanaan pemanfaatan media pemasaran online bagi industri konveksi rumahan di desa Jolotundo

b. Menganalisis proses pelaksanaan siklus keuangan akuntansi yang dapat diterapkan pada Usaha Kecil Menengah

c. Mengamati pentingnya melaksanakan program PKMS karena latar belakang mitra dan kondisi yang dialami mitra

d. Menyusun waktu pelaksanaan kegiatan PKMS

e. Mempersiapkan peralatan dan perlengkapan dalam implementasi PKMS

f. Mempersiapkan tim pelaksana untuk melakukan kegiatan PKMS

\section{Pelaksanaan}

Metode pelaksanaan

a. Melihat kondisi UKM mitra yang akan diamati mengenai pemasaran usaha dan kondisi pencatatan keuangannya yang telah dilakukan selama ini baik sebelum, saat dan setelah terjadinya proses

b. Mengidentifikasi dan merumuskan permasalahan yang terjadi pada UKM mitra. Aktivitas pemasaran antara lain dari mulai dokumentasi produk-produk baju hasil produk mitra, kemudian hasil dokumentasi dimasukkan dalam menu $e$ commerce. Aktivitas keuangan pada UKM antara lain dari mulai proses pembelian bahan baku dan bahan penolong, pembelian secara tunai, proses penjualan sampai 
perhitungan laba/rugi dan gaji pegawai serta transaksi lain yang menunjang kegiatan UKM Mitra.

\section{Sosialisasi dan Pelatihan}

Sosialisasi dan pelatihan dilakukan untuk memberikan pemahaman kepada mitra tentang pentingnya pengelolaan usaha menggunakan manajemen baik. Sosialisasi dan pelatihan dilakukan selama 1 minggu dengan cara berkunjung ke tempat usaha mitra dan memberikan pengarahan tentang manajemen pemasaran dan keuangan. Dalam masa ini juga dimaksudkan untuk mencari masukan-masukan dari mitra tentang penerapan manajemen yang mencakup: pemasaran dan keuangan.

\section{Pendampingan teknik penyusunan} akuntansi

Tahap yang pertama adalah pencatatan. Tahap pencatatan merupakan pencatatan transaksi yang bersumber pada bukti transaksi. Tahap ini meliputi penjurnalan dan pemindahbukuan. Penjurnalan merupakan tahap meringkas transaksi dan menentukan posisi debet kredit pada akun-akun yang bersangkutan.

5. Mengajak dan mendorong Pemerintah Kabupaten Rembang, Dinas Perindustrian, Perdagangan, Koperasi dan UKM (Dinindagkop dan UKM) untuk lebih memperhatikan industri konveksi rumahan di Desa Jolotundo sebagai salah satu aset Desa Jolotundo Kecamatan Lasem.

\section{HASIL}

Pelaksanaan program PKMS kelompok Jahit Kenanga Desa Jolotundo, Kecamatan Lasem Kabupaten Rembang, Tim telah melakukan kegiatan beberapa hal, yaitu:

1. Memberikan penyuluhan kepada kelompok jahit

Penyuluhan kepada kelompok jahit mengenai pentingnya/manfaat adanya kelompok di Desa Jolotundo Kecamatan Lasem Kabupaten Rembang. Kegiatan ini dilakukan pada bulan pertama, yaitu tepatnya pada hari Selasa, 9 April 2019. Penyuluhan kepada kelompok jahit dilaksanakan setelah pembukaan kegiatan PKMS yang dihadiri oleh kepala Desa Jolotundo dan Ketua LPPM STIE YPPI Rembang. Respon dari anggota kelompok jahit sangat baik dan penuh semangat. Para anggota kelompok jahit "Kenanga" bisa memahami pentingnya peran kelompok dalam memajukan usaha. 


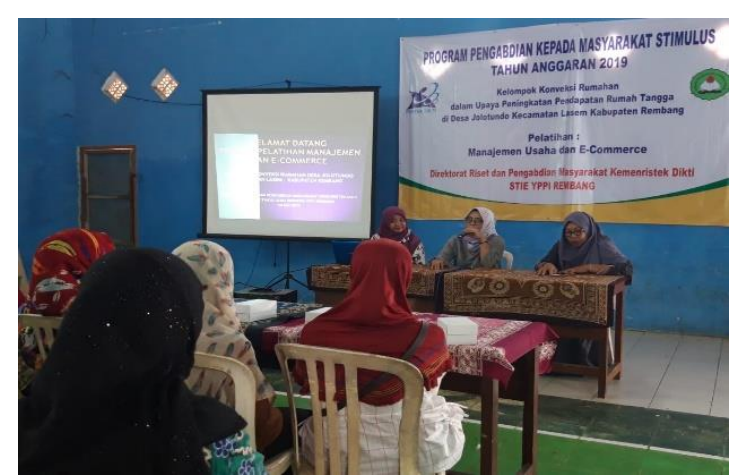

Gambar 1 Pembukaan Kegiatan PKMS

2. Memberikan Pelatihan Manajemen Usaha dan E-Commerce

Setelah kegiatan PKMS secara resmi dibuka oleh Ibu Kepala Desa Jolotundo dan Ibu Ketua LPPM STIE YPPI Rembang. Untuk selanjutnya dilakukan Pelatihan Manajemen Usaha yang meliputi: manajemen produksi, motivasi dan manajemen keuangan. Pelatihan Manajemen Usaha dan E-Commerce diselenggarakan pada hari Rabu, 31 Juli 2019. Pelaksanaan Pelatihan manajemen usaha meliputi: motivasi berwirausaha, manajemen produksi, manajemen keuangan, praktek membuat laporan keuangan dan e-commerce. Pelatihan diikuti sebanyak 10 orang yang tergabung dalam kelompok jahit. Kegiatan tersebut juga kami publikasikan di media massa Jawa Post pada hari Senin, 5 Agustus 2019.

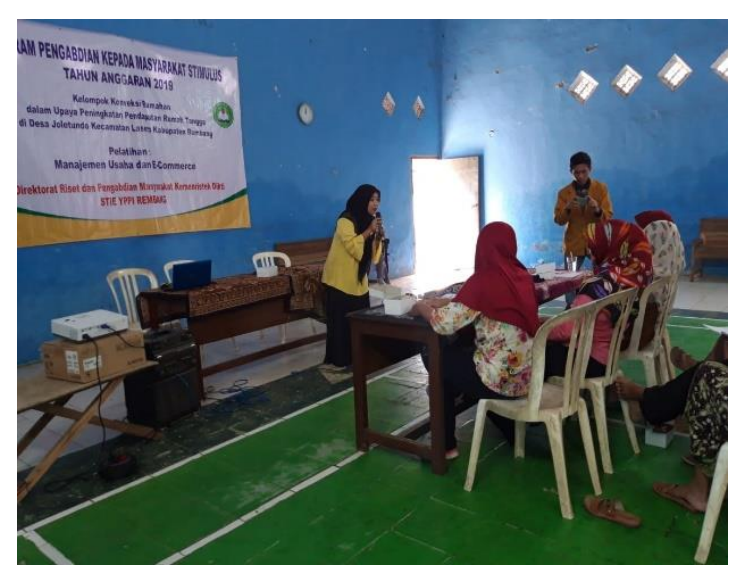

Gambar 2 Pelatihan Manajemen Usaha

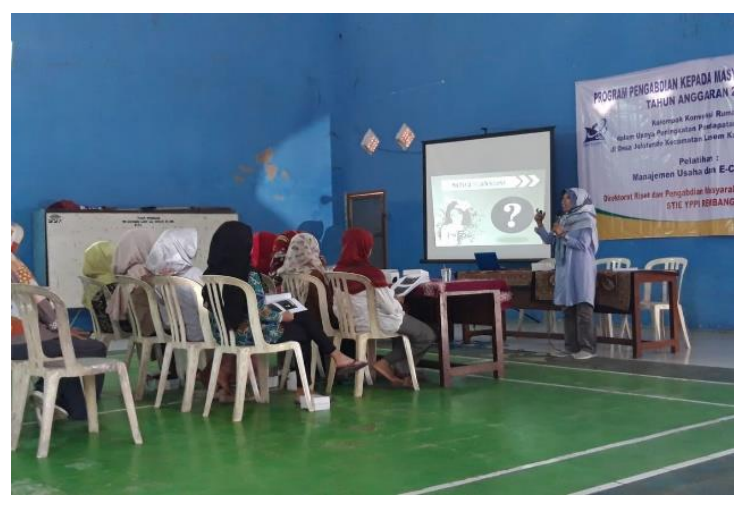

Gambar 3 Pelatihan E-Commerce

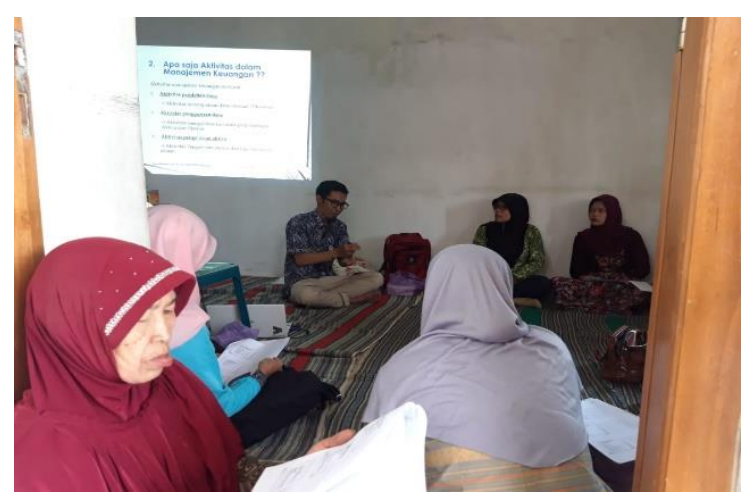

Gambar 4 Pelatihan manajemen keuangan 


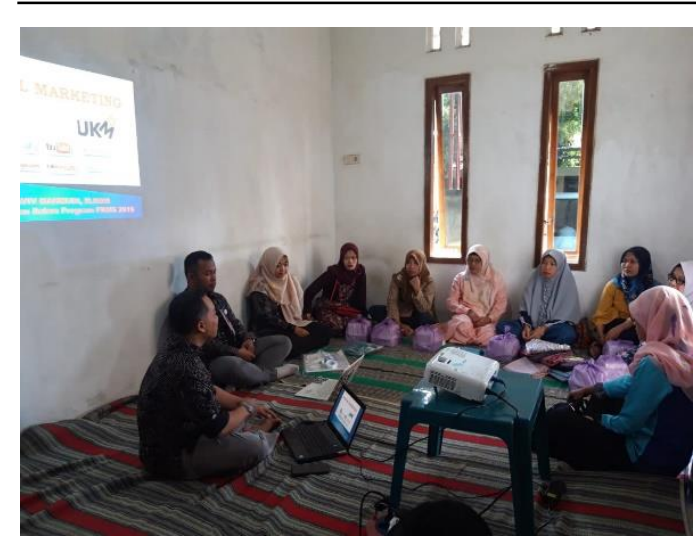

Gambar 5 Pelatihan Manajemen Keuangan

\section{PEMBAHASAN}

Keseluruhan program kemitraan masyarakat berjalan dengan baik dan disambut antusias. Pembahasan masingmasing kegiatan untuk mempertajam kebermanfaatan dan keberhasilan program adalah sebagai berikut:

1. Hasil dari pelatihan manajemen dan kewirausahaan yaitu peserta pelatihan mulai memperhatikan kualitas atau model baju yang akan mereka buat. Mitra mulai memanfaatkan katalog atau modelmodel baju

2. Mitra mulai untuk melakukan pembukuan sederhana, setiap pemasukan dan pengeluaran telah dilakukan pencatatan ke dalam sebuah buku. Kebermanfaatan dari setiap pencatatan yang telah dilakukan, mitra mulai mampu membandingkan jumlah pemasukan dan pengeluaran setiap bulannya
3. Untuk mengenalkan hasil kelompok jahit Kenanga Tim PKMS membuat logo merk. Merk produk hasil kelompok jahit Desa Jolotundo adalah "Kenanga". Nama merk tersebut diambil dari nama kelompok usaha. Selain membuat nama merk, Tim dan kelompok juga membuat logo merk usaha. Dengan adanya logo tersebut diharapkan dapat lebih dikenal masyarakat.

4. Untuk menambah nilai sebuah produk, untuk hasil produk kelompok kenanga telah tersedia kemasan produk

5. Mitra mulai berpikir untuk melakukan produksi yang tidak hanya berdasarkan pada pesanan saja, namun mitra telah mulai membuat stok untuk dipasarkan secara online

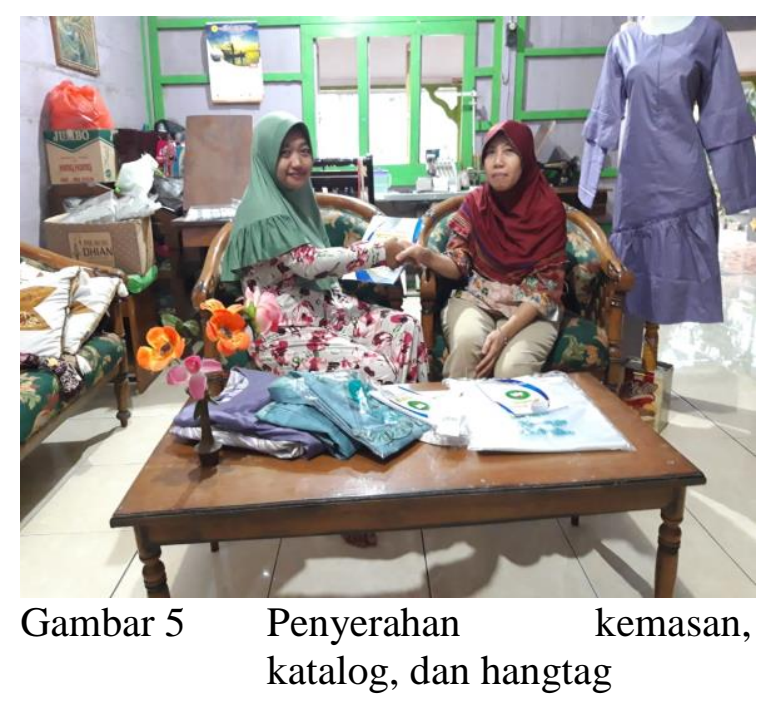




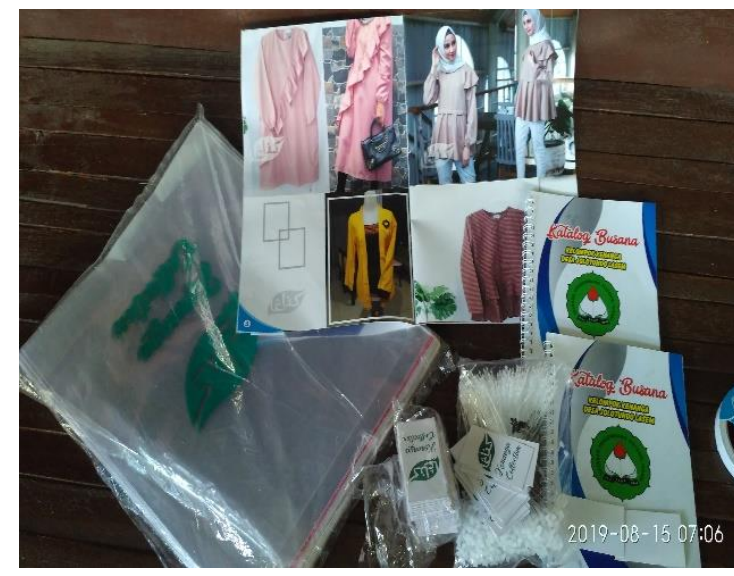

Gambar 6 Kemasan, Katalog, Hangtag

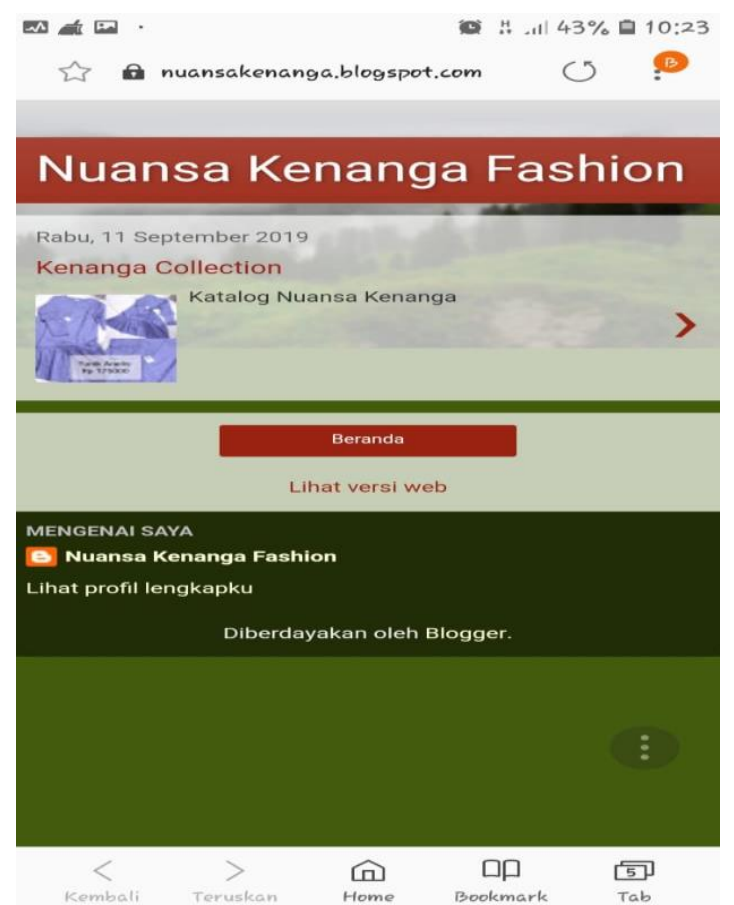

Gambar 7 Blog Nuansa Kenanga Fashion

\section{KESIMPULAN}

Dari hasil kegiatan ini dapat disimpulkan hal-hal sebagai berikut:

1. kelompok mitra mampu membuat toko online (Tokopedia) serta blog

2. kelompok mitra mampu membuat pembukuan keuangan yang tertib dan baik
3. kelompok mitra mulai berani membuat produk dengan tanpa mengandalkan pesanan,

4. produk kelompok mitra telah menggunakan kemasan dengan dilengkap hangtag dan merk pada produk.

\section{SARAN}

Perlu adanya pendampingan penyusunan laporan keuangan dan monitoring atas pemasaran yang dilakukan online dan efeknya terhadap peningkatan pesanan

\section{UCAPAN TERIMA KASIH}

1. Kementerian Riset, Teknologi, dan Pendidikan Tinggi, Direktorat Jenderal Pembelajaran dan Kemahasiswaan khususnya Direktorat Riset dan Pengabdian Masyarakat yang telah mendanai pelaksanaan program pengabdian ini.

2. LLDIKTI VI Jawa tengah yang telah mengkoordinir dan memfasilitasi pelaksanaan pengabdian kepada masyarakat ini.

3. Lembaga Penelitian dan Pengabdian kepada Masyarakat STIE YPPI Rembang yang telah mengkoordinir terlaksananya program pengabdian ini. 
4. Kelompok konveksi Kenanga yang telah bersedia untuk menjadi mitra dalam pelaksanaan program pengabdian ini.

\section{DAFTAR PUSTAKA}

Badan Pusat Statistik Kabupaten Rembang, (2016), “Kecamatan Lasem Dalam Angka”.

Direktorat Penelitian dan Pengabdian Kepada Masyarakat, Direktorat Jenderal Pendidikan Tinggi, Kementerian Pendidikan dan Kebudayaan, (2017), "Panduan Pelaksanaan Penelitian dan Pengabdian Kepada Masyarakat Di Perguruan Tinggi", Edisi XII.

Disperindagkop dan UMKM Kabupaten Rembang, (2016), “Data UMKM Industri di Kabupaten Rembang”.

Shonhadji Nanang, (2017), “Penerapan Penyusunan Laporan Keuangan Pada Usaha Kecil Menengah Berdasarkan SAK EMKM di Surabaya, Prosiding Seminar Nasional Hasil Pengabdian kepada Masyarakat (SENIAS), Universitas Islam Madura, 2017
Wahyuningsih Endang Dwi, dkk, (2017), "Pemberdayaan Pelaku Usaha Mikro Dengan Memberikan Pelatihan Pembukuan Sederhana di desa Bangunrejo Kecamatan Patebon Kabupaten Kendal", Prosiding Seminar Nasional Hasil-Hasil Penelitian dan Pengabdian Msyarakat, UMS, 2017. 